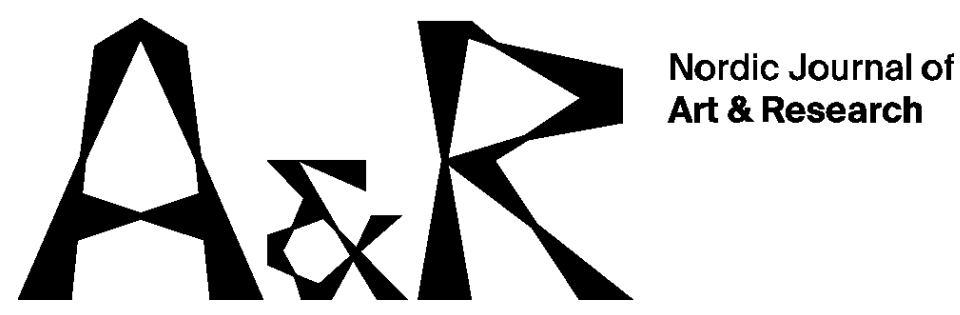

ISSN: 1893-2479

www.artandresearch.info

\title{
Tro, musikalske røtter og anerkjennelse i en krysskulturell kontekst
}

Irene Trønnes Strøm ${ }^{1}$

Høgskulen i Innlandet

\begin{abstract}
Sammendrag: Artikkelen dreier seg om betydningen av å anerkjenne egne og andres musikalske røtter. Utgangspunkt for tematikken er hvordan opplevelser av ubehag kan oppstå i situasjoner der religiøst musikalsk innhold er brakt spontant inn i undervisningen av musikklærerstudenter. Artikkelen bygger på erfaringer fra egen lærerutdanningspraksis og kvalitative data samlet inn i forbindelse med mitt doktorgradsprosjekt (Strøm, 2016). Intervjuer med ungdommer som vokser opp i en krysskulturell kontekst danner artikkelens kjerne. Disse dataene brukes for å belyse forholdet mellom religiøs tro og musikalsk identitet samt ressurser og utfordringer som noen av disse ungdommene kan kjenne på i utøvingen av sine musikalske aktørskap. Artikkelen anvender Stones' (2005) strukturasjonsteori, kalt «strong structuration», som utgangspunkt for å si noe om forholdet mellom aktør og struktur. Jeg ønsker med denne artikkelen å argumentere for krysskulturbegrepets relevans i en musikkundervisningssammenheng samt bidra til økt forståelse for og anerkjennelse av elevers religiøse musikalske røtter og identitet i musikkfaget i grunnskolen.
\end{abstract}

Emneord: musikalske røtter, musikalsk aktørskap, musikalsk identitet, sterk strukturasjon, religion, spiritualitet, krysskultur, anerkjennelse

\section{Innledning}

«Min båt er så liten og havet så stort» ${ }^{2}$ - de to musikklærerstudentene sitter forrest $\mathrm{i}$

klasserommet og nynner svakt mens de fyller ut et skjema om barns musikalske utvikling. Det er profesjonsfag på faglærerutdanningen i musikk og jeg har gitt studentene i oppgave å fylle inn sanger og regler i skjemaet ettersom de synes disse passer i møte med barn mellom 0 og 6

\footnotetext{
${ }^{1}$ Førsteamanuensis ved Høgskolen i Innlandet, Fakultet for lærerutdanning og pedagogikk, institutt for kunstfag og kulturstudier. E-mail: irene.strom@inn.no

${ }^{2}$ «Min båt er så liten» har vært kjent som en søndagsskolesang siden 1870-tallet. Melodien er av svensk opprinnelse. Teksten har likhetstrekk med The Old Breton prayer «Thy sea, O God so great, my boat so small».
} 
år. En annen student bryter spontant ut i sangen «Måne og sol, skyer og vind» ${ }^{3}$ mens hun jobber med oppgaven. Hun synger hele første vers og et refreng med full stemme og et blidt ansikt. Reaksjoner fra medstudenter viser at noen av dem opplever et visst ubehag i denne situasjonen. Det synges ingen andre sanger i løpet av undervisningsøkten.

Jeg underviste dette temaet $i$ to ulike grupper to påfølgende studieår, og noe lignende skjedde ved begge tilfellene. Opplevelser av ubehag kom til uttrykk blant annet ved en viss bekymring for de nynnende studentene, mens andre studenter uttrykte at slike barnesanger ikke hører hjemme i grunnskolen - til tross for at oppgaven ikke gikk ut på å foreslå et passende repertoar for musikkfaget i grunnskolen. Ved det første tilfellet var jeg ikke forberedt på at en slik situasjon kunne oppstå, så jeg lot hendelsen passere uten å kommentere verken syngingen eller de påfølgende reaksjonene. Den andre gangen hadde jeg derimot hatt anledning til å reflektere over den første hendelsen slik at jeg var rede til å samtale med studentene om deres ulike utgangspunkter for å løse oppgaven.

Tilbakemeldingene fra medstudenter om at søndagsskolesanger ikke er et passende repertoar for musikkfaget $\mathrm{i}$ grunnskolen kan forstås på flere ulike måter. På den ene siden kan utsagnet forstås som en inkluderende holdning til religiøs diversitet i et mangfoldig samfunn, der er ikke én religion fremheves fremfor andre. På den andre siden kan det forstås som en uavklart holdning til betydningen av skillet mellom religiøst repertoar brakt inn i undervisningen av musikklæreren og det religiøse repertoaret som den enkelte elev bringer med seg til musikkfaget i en krysskulturell kontekst. I denne sammenheng utforsker artikkelen hvordan ungdom som vokser opp i krysskulturelle kontekster verbaliserer betydningen av religion i relasjon til musikk. Studien «Jeg er ikke norsk, vet du, jeg er internasjonal - En etnografisk studie av musikalsk aktørskap blant ungdom i krysskulturelle kontekster» (Strøm 2016) viser hvordan noen av informantene opplevde både gleder og utfordringer i relasjonen mellom religiøs tro og utøvingen av sine musikalske aktørskap. Krysskulturell viser til den unike miksen som oppstår når barn og unge vokser opp med påvirkning fra flere kulturer samtidig eller vekselvis. Musikalsk aktørskap forstås i denne sammenhengen som individets evne til å engasjere seg aktivt og ta selvstendige grep i sitt eget forhold til musikk. Som lærerutdanner med religiøse musikalske røtter, som har forsket på krysskulturelle kontekster, kan jeg kjenne meg igjen i flere av disse ungdommenes fortellinger.

Det at det norske samfunnet er blitt så krysskulturelt kan ifølge Nerland (2004) gi mange muligheter, men også mange utfordringer for musikkutdanning som disiplin. Hun hevder at det kan synes å være en utfordring for musikkpedagogisk virksomhet å møte elevene i deres erfaringsverden «og slik kunne tilskrive de musikkulturelle ferdighetene de har ervervet, verdi i undervisningssituasjonen» (s. 142). Fitzpatrick (2012) viser til at det å kjenne til «your students' cultural backgrounds - as well as recognizing your own - can foster greater respect, clearer understanding, and better connections in the music classroom» (s. 53). På samme måte som Nerland (2004) ser hun dette som en forutsetning for at musikkutdanning blir verdsatt av studentene som en arena for identitetskonstruksjon og personlig investering. Løvlie Schibbye (1993) hevder at «recognition or acknowledgement is necessary for genuine or transcendental change ... in relationships in general (s. 175). Videre sier hun at «to recognize the other person's experiential field means that you enter into it, share it, affirm it, and above all that you are mindful of the other person's absolute right to his or her own experience (original kursiv, s. 183). Dette er et svært relevant perspektiv i denne sammenhengen siden koblingen mellom religion og musikk kan synes ekstra viktig for ungdom med krysskulturell bakgrunn. Hovedfokus i denne artikkelen vil derfor være på ungdommers fortellinger om deres religiøse erfaringer i forhold til musikk og utfordringer med å

\footnotetext{
3 «Måne og sol» er en salme for barn fra 1974 med tekst skrevet av den svenske poeten og oversetteren Britt G.
} Hallquist, og melodien er komponert av den norske organisten Egil Hovland. Teksten handler om Treenigheten. 
navigere mellom egen overbevisning og deres omgivelser. Ved å diskutere forholdet mellom musikk, religion og skole ønsker jeg å bidra til en bevissthet rundt hvordan musikklærere i krysskulturelle kontekster kan styrke barns og unges musikalske aktørskap ved å anerkjenne deres musikalske røtter, og dermed bygge broer og forståelse mellom elever med ulik kulturell bakgrunn. Hørbare uttrykk for og opplevelser av ubehag i denne sammenhengen må tas på alvor og være en del av denne diskusjonen. Problemstillingen for artikkelen høres dermed slik ut:

Hvordan kan kunnskap om forholdet mellom musikk og religion blant ungdom som vokser opp i en krysskulturell kontekst bidra til økt forståelse for og anerkjennelse av elevers religiøse musikalske røtter og identitet i musikkfaget i grunnskolen?

\section{Krysskultur versus flerkultur}

Begrepet krysskulturell, eller «cross-cultural» på engelsk, oversettes gjerne med flerkulturell. Mens flerkulturell kan «gi assosiasjoner til lett identifiserbare deler som kan plukkes ryddig fra hverandre» (Salole, 2013, s. 29), så viser krysskulturell som nevnt til den unike miksen som oppstår når barn og unge vokser opp med påvirkning fra flere kulturer samtidig eller vekselvis (Strøm, 2016). Barn og unge som migrerer, eller som vokser opp i krysskulturelle kontekster, vil måtte forholde seg til kryssende verdenssyn, livssyn, verdier og levesett, og i disse møtene vil den individuelle aktøren måtte ta en lang rekke valg. I hvilken grad dette er motiverte, ubevisste, selvbestemte eller påtvungne valg vil variere både med konteksten og aktørens muligheter og personlighet. Det ligger til grunn for denne artikkelen at aktøren til enhver tid er situert i ulike kontekster og at aktørers handlinger påvirkes av både interne og eksterne strukturer som aktøren har mer eller mindre kontroll over. Når disse kontekstene består av en blanding av ulike etnisiteter og kulturer, vil den enkelte måtte forholde seg til likheter og ulikheter mellom disse kulturene, og det vil kunne oppstå kryssende forventninger. I dette skjæringspunktet vil det oppstå en miks, eller en blanding, der individet blir påvirket av hver av de aktuelle kulturene det forholder seg til.

Krysskultur kan også beskrives med referanse til et tre med kryssende røtter. Røttene vokser over og inn i hverandre og kan være umulige å skille. Hvert tre er unikt, med sitt eget rotmønster, «[s]amtidig er alle røttene festet til forskjellige steder, og gir treet næring fra hvert sitt hold. Røttene forankrer treet og holder det fast der det vokser fra, selv når det stormer, regner og snør» (Salole, 2018, s. 37). Videre er rollen som brobygger og kulturell tolk en utbredt erfaring blant ungdom med krysskulturell bakgrunn. Brobyggerrollen kan oppleves krevende fordi man hele tiden må kunne forklare og forsvare ting fra ulike perspektiver. Salole oppmuntrer derfor til å identifisere og anerkjenne ressurser knyttet til en krysskulturell oppvekst og samtidig gi rom for «å være og mene både-og» (s.176). Anerkjennelse innebærer ifølge Bae og Waastad (1992) å kunne akseptere motsatte og paradoksale perspektiv. Dette igjen forutsetter «toleranse for det udefinerte og evne til å leve relasjoner som et både-og-fenomen og ikke som et enten-eller-fenomen» (s. 25). Det å vokse opp i en krysskulturell kontekst tilbyr et stort spekter av måter å være musikalsk aktør på. For en ungdom med religiøse musikalske røtter betyr dette at hun må gjøre daglige valg knyttet til hvilken musikk hun kan lytte til, hvilke musikalske sjangre hun kan utøve og hvordan hun bruker musikk som ressurs i ulike livssituasjoner (Strøm, 2016). Kryssende kulturelle erfaringer kan imidlertid også ungdom med norsk bakgrunn erfare, for eksempel når de flytter fra én landsdel til en annen. Musikk inngår i krysskulturelle forhandlinger og erfaringer fordi musikk på helt spesielle måter er forbundet med selvforståelse og identitetsbyggende prosesser, og fordi musikk tilbyr et rikt spekter av bruksområder og funksjoner i den musikalske aktørens liv. Ungdom som vokser opp i dagens krysskulturelle Norge kan ikke velge bort mangfoldet, men de må velge hvordan de skal forholde seg til det. 


\section{Religion i et krysskulturelt Norge}

De siste ti årene har antallet innvandrere og norskfødte ${ }^{4}$ Norge tredoblet seg (Statistisk Sentralbyrå, 2017a). Dette skyldes først og fremst arbeidsinnvandring fra de nye EU-medlemslandene fra ØstEuropa og de mange flyktningene ${ }^{5}$ som har funnet sin vei til Norge. Til tross for at innvandringen har $ø k t$ sterkt de siste ti årene så er Norge et forholdsvis ungt krysskulturelt land, i sammenligning med for eksempel Canada, som innførte en offisiell politikk for multikulturalisme allerede i 1971. I dette lyset mener jeg at Norge kan forstås som et nokså monokulturelt samfunn der norske verdier og norsk kultur fremdeles står ganske sterkt i folks bevissthet. Norske selvforståelser utfordres i møte med økt innvandring og et større kulturelt og religiøst mangfold. Religiøs diversitet er en viktig del av et krysskulturelt Norge og en økning i medlemstallet for ulike trossamfunn har en klar sammenheng med innvandringen til Norge (Statistisk Sentralbyrå, 2012). Religiøs tilhørighet er imidlertid ikke så lett å tallfeste, men undersøkelsen viser at mer enn ti prosent av Norges befolkning var medlemmer av et trossamfunn utenfor Den norske kirke i 2017. Blant disse er katolikker den klart største gruppen, blant annet som en følge av innvandringen fra østeuropeiske land. Videre antar man at ca. $4 \%$ av befolkningen er muslimer (Statistisk Sentralbyrå, 2017b). Levekårsundersøkelsen blant innvandrere (Statistisk Sentralbyrå, 2016) viser at religion er viktig for mange innvandrere. De fleste av informantene svarte at de fortsatt tilhører den religionen de er blitt oppdratt i. Mange barn av innvandrere oppga imidlertid at de var mindre religiøse enn sine foreldre. Man ser altså en sekularisering også blant innvandrere, i likhet med resten av det norske samfunnet.

\section{Religion i lys av begreper om spiritualitet}

Historisk sett har ordene religiøs og åndelig, eller spirituell, blitt brukt synonymt for å beskrive ulike aspekter av begrepet religion. Ifølge Matsunobu (2007) handler et skille mellom spiritualitet og religion om at det første kan forstås som et grunnlag for eksistensiell erfaring, mens det andre snarere kan forstås som et veivalg eller en sti. Han refererer, som Salole (2018), til treet som metafor for å forklare forskjellen og forbindelsen mellom disse begrepene. Røttene forstås i denne sammenhengen som spiritualitet og bladene som religion. Slik jeg tolker dette kan religiøse praksiser videre forstås som treets frukter. I følge Kunnskapsløftet er musikkopplevelsen «uforutsigbar, men ikke forutsetningsløs» (Utdanningsdirektoratet, 2006): «I dette ligger erkjennelsen av at musikkopplevelsen ikke bare er intuitiv, men at kjennskap til musikk ... og refleksjon om musikk til sammen danner grunnlag for musikkopplevelsen forstått både som estetisk opplevelse og eksistensiell erfaring» (Læreplan i musikk). Slik jeg ser det representerer religiøse retninger og tradisjoner i denne sammenhengen ulike veivalg som den musikalske aktøren kan ta i sin søken etter å oppleve livets dype realiteter, i denne sammenheng forstått som eksistensiell erfaring.

Religiøs musikalsk erfaring kan være relatert til dype lag i individets kroppslige og åndelige erfaringsverden. Religion har ifølge Yob (2011) formet og blitt formet av den spirituelle erfaringen, «but does not have exclusive rights to spirituality» (s. 44). Det er med andre ord ingen selvfølge at eksistensiell erfaring oppleves som den eneste farbare veien for å oppleve meningen med livet. Ruud (2013) refererer til «det transpersonlige rom» som noe som er forankret utenfor oss selv «i noe grensesprengende, noe bortenfor de nære tids- og romdimensjoner» (s. 236). Den musikalske aktøren

\footnotetext{
${ }^{4}$ Innvandrere er, ifølge SSB (Statistisk Sentralbyrå, 2018), personer født i utlandet av to utenlandskfødte foreldre som har fire utenlandskfødte besteforeldre. Norskfødte med innvandrerforeldre er født i Norge og har to foreldre som selv har innvandret. Innvandrere og norskfødte med innvandrerforeldre utgjorde 884000 personer, eller $16,8 \%$ av den totale befolkningen i begynnelsen av 2017.

${ }^{5}$ De fleste fra Syria, Afghanistan og Irak (Statistisk Sentralbyrå, 2017a)
} 
har på denne måten mulighet til å knytte musikken an til åndelige eller spirituelle opplevelser gjennom å realisere et behov for å bli løftet opp fra hverdagen eller det å se seg selv i et større perspektiv (Bernard, 2009, van der Merwe \& Habron, 2015). I en krysskulturell kontekst vil imidlertid relasjonen mellom musikk og religiøs tro kunne oppleves som et konfliktfylt forhold, siden normer for «riktig» og «gal» måte å forholde seg til musikk på vil kunne variere (Harris, 2006). Slike forhandlinger kan forstås som spesielt avgjørende i krysskulturelle kontekster siden individer kan måtte komme til å forhandle mellom motstridende verdigrunnlag når de beveger seg mellom de ulike kulturene som deres hverdag består av, jamfør treets kryssende røtter.

\section{Forskning på musikalsk aktørskap og krysskulturell musikkopplæring}

Forskning på krysskulturell musikkopplæring og musikalsk utøving har en lang historie der sentrale aktører har diskutert hvordan mangfoldet av verdensmusikk skal anerkjennes og implementeres i musikklasserommet (Campbell, et al., 2005; Elliott, 2013; Schippers, 2010; Volk, 1998). Min studie (Strøm, 2016) inngår i en rekke av nyere studier på krysskulturell musikkopplæring og musikalske praksiser med et erfaringsbasert fokus, som vektlegger betydningen av at unge mennesker får definere og integrere sin «egen» musikk (Sæther, 2008, 2010; Nethsinghe, 2012; Cain, 2015; Heimonen \& Westvall 2015; Karlsen \& Westerlund, 2015; Westerlund, Partti \& Karlsen, 2016; Karlsen, 2017; Kvaal, 2018).

Karlsen og Westerlund (2010) argumenterer for at musikk og opplæring for ungdom med ulik kulturell bakgrunn henger sammen med utviklingen av sunne demokratiske praksiser $\mathrm{i}$ utdanningssammenheng. Arbeidet er knyttet til et større skandinavisk forskningsprosjekt (Karlsen, 2011, 2012, 2013, 2014, 2015). Funnene viste at elevenes handlinger med musikk var rike og komplekse, og dette er tatt som et utgangspunkt for en drøfting av funnenes potensial for å informere læreres praksis i krysskulturelle musikklasserom. I stedet for å inkludere musikk som korresponderer med elevenes bakgrunn, foreslår Karlsen (2013) et rammeverk som er lydhørt overfor elevenes identiteter og kapasiteter «uten å svekke deres rett til selvdefinisjon for å uttrykke sin egen kompleksitet» (min oversettelse, Karlsen, 2013, s. 173). Ifølge Salole (2018) kan dette som nevnt handle om «jakten etter en trygg både-og-identitet» (s. 250). Det å ha en krysskulturell bakgrunn eller å vokse opp i en kontekst med et stort kulturelt mangfold, kan forstås både som tilganger på rike ressurser og kilder til stadige konfrontasjoner mellom kryssende verdisett og livsanskuelser i et stadig mer mangfoldig Norge. For barn og unge som vokser opp i krysskulturelle kontekster handler dette «om å kunne forene sine verdener og forsone seg med å være sammensatt» (s. 250). Dette kan videre bety å måtte forholde seg til både kryssende røtter og sammenfiltrede greiner.

\section{Teoretiske tilnærminger og begreper}

Innenfor sosiologisk teori finnes det ulike tilganger til å snakke om menneskelige handlinger som utøvelse av aktørskap. I denne artikkelen anvendes Stones' (2005) strukturasjonsteori, kalt «strong structuration», som utgangspunkt for å si noe om forholdet mellom aktør og struktur. Aktørskap handler for Stones om situerte handlinger og interaksjoner basert på strukturer som aktørene drar veksler på av ren rutine eller på kreative måter. Med andre ord eksisterer det en dualitet mellom strukturen og aktøren der disse er gjensidig avhengig av hverandre. Han ønsker å ta vare på styrkene i Giddens' (1984) opprinnelige strukturasjonsteori og samtidig revidere den for at den skal bli mer brukbar i empiriske undersøkelser med et situasjonsnært fokus. Mens Giddens legger vekt på aktørens «knowledgeability», hevder Stones (2005) at det er snakk om grader av kunnskapsevne der aktøren 
har mer eller mindre kunnskapsevne og kritisk refleksjon og at hun har flere eller færre valgmuligheter med forutsette eller uforutsette konsekvenser. Sterk strukturasjon legger vekt på at aktøren handler ut fra verdiforankringer, forstått som en plattform av verdier, holdninger, livsanskuelser og fortolkninger, som aktøren drar veksler på når han handler, men som samtidig kan virke begrensende på aktørens mulighet til å ta de valgene han ønsker.

Stones (2005) konseptualiserer aktørskap som et aktivt anliggende der aktøren bygger på både eksterne og interne strukturer. Situerte aktører med bestemte meningsrammer kan føle seg både i stand til og ute av stand til å motstå, regulere eller kontrollere «putative causal impositions of external structures» (s. 113). Dette er et svært relevant perspektiv i en krysskulturell kontekst siden aktørene kan føle seg mer eller mindre presset til å følge kulturelle normer som skiller seg sterkt fra tradisjonelle norske verdier. Aktøren trenger derfor, ifølge Stones, adekvat makt, kunnskap og kritisk distanse for å kunne motstå eksterne strukturer. Slik jeg ser det handler det i like stor grad om å kunne motstå interne strukturer, som for eksempel internaliserte religiøse og kulturelle normer og verdier. Selv om aktøren kunne motstått interne eller eksterne strukturer er det viktig for Stones å fremheve at aktøren ofte velger å ikke gjøre opprør. Stones viser blant annet til hvordan jødiske bosetninger valgte å arbeide på sabbaten da de emigrerte til Amerika på slutten av 1800-tallet siden andre folk brukte denne dagen til å handle. Valget mellom fattigdom og evne til å brødfø familien resulterte i en reorganisering av målhierarkiene og en stilltiende aksept av at fedrene ikke deltok ved sabbatsmåltidet.

Stones' firedelte strukturasjonsmodell (s. 85) involverer eksterne strukturer som handlingsvilkår, interne strukturer i aktøren, aktive aktørskap der aktøren trekker på interne strukturer når hun handler og resultater forstått som nye strukturer eller hendelser. De interne strukturene deles inn i to analytiske komponenter; situasjonsspesifikke strukturer og generelle disposisjoner. De situasjonsspesifikke strukturene handler om aktørens kunnskap om den spesifikke konteksten hun befinner seg i, mens de generelle disposisjonene inkluderer evner, ferdigheter og holdninger, språklige vaner og gester og måter som aktøren tilpasser seg bestemte praksiser på. Musikalske røtter kan forstås som en kombinasjon av de to interne strukturene. Fokuset er på den situerte aktørens aksjonshorisonter slik som disse oppfattes av aktøren selv eller av forskeren. Når situerte aktører kunne valgt å handle annerledes («doing otherwise», Giddens, 1984), men velger å ikke gjøre dette, kaller Stones (2005) de eksterne strukturene for uimotståelige kausale krefter (s. 111). Ungdommene som vi møter i denne artikkelen tar svært ulike valg når det gjelder deres forhold til slike strukturer. Stones hevder imidlertid at det er like mye verdighet i en aktørs valg om å bare «'carry on’ instead of doing otherwise» (s. 113), og på den måten finne verdi og mening i livet slik som det er.

\section{Metode}

Empiriske studier som benytter sterk strukturasjon må ifølge Stones involvere både situert analyse og strukturell analyse. I denne forbindelse anbefaler han to former for analytiske grep, jamfør aktørens interne strukturer. Disse har jeg valgt å kalle aktørens handlingsanalyse og aktørens kontekstanalyse. Mens handlingsanalysen leder forskeren til aktøren selv; «her reflexive monitoring, her ordering of concerns into a hierarchy of purposes, her motives, her desires, and the way she carries out the work of action and interaction» (s. 122), handler kontekstanalysen om «the terrain that faces an agent, the terrain that constitutes the range of possibilities and the limits to the possible» (s. 122). I denne artikkelen ligger fokuset først og fremst på handlingsanalysen ${ }^{6}$ og hva ungdommene fortalte om sine egne musikalske aktørskap. Ungdommenes handlinger, knyttet til musikalsk og religiøs erfaring i en

\footnotetext{
${ }^{6}$ For lesere som er interessert i kontekstanalysen viser jeg til kapittel fem i avhandlingen (Strøm, 2016).
} 
krysskulturell kontekst, kan med strukturasjonsteoretiske begreper forstås som en pågående prosess, som involverer både deres interne og eksterne strukturer, med ulike resultater.

De empiriske dataene i studien ble samlet inn gjennom et etnografisk feltarbeid som inkluderte observasjoner, kvalitative intervjuer og uformelle samtaler. Feltarbeidet varte i 6 måneder, fra januar til juni 2014. Jeg gjennomførte til sammen 20 intervjuer. I denne artikkelen skal jeg konsentrere meg om intervjuene med de seks ungdommene Anniken, Ester, Jack, Nadege, Naomi og Rebekka. Det var særlig disse som uttalte seg om betydningen av religiøse erfaringer knyttet til musikk. Naomi og Jack hadde muslimsk bakgrunn, mens Nadege og venninnene Ester og Rebekka hadde kristen bakgrunn7. Anniken så ikke på seg selv som religiøs. På tidspunktet for intervjuene var disse i alderen 15-19 år. Ester og Naomi var deltagere på et privat kultursenter for krysskulturell ungdom, mens Anniken, Nadege og Rebekka var deltakere på et nordisk kurstilbud for krysskulturell ungdom i kommunal regi. Jack benyttet seg av det kommunale ungdomshusets øvingsrom, studio og scener. Intervjuene ble gjennomført på ulike steder; på det kommunale kulturhuset, i bilen min og i en park. Alle intervjuene, unntatt ett, ble gjennomført på norsk. Intervjuet med Nadege ble gjennomført på engelsk og sitatene fra dette intervjuet har jeg oversatt til bokmål.

Analysen tar utgangspunkt i Karlsens (2011) analytiske linse for musikalsk aktørskap. I tilknytning til denne linsen har Karlsen utarbeidet fem analytiske filtre ${ }^{8}$ som fungerer som finstillinger av linsen. Med utgangspunkt i denne linsen har jeg utarbeidet mine egne analytiske filtre: lytting, utøving, livsressurs, læring og sansing. Disse analytiske filtrene har sammenheng med både teoretiske og empiriske kategorier. Kategorien sansing handler om erfaringer knyttet til musikk og religion, tro og kryssende verdier. Musikk brukt for «det å være» («being», Karlsen, 2011), forstått som en ressurs for det å oppfylle eksistensielle behov (DeNora, 2000), er et viktig trekk ved ungdommenes fortellinger om sine musikalske aktørskap. Flere av dem måtte forhandle mellom til dels motstridende verdigrunnlag når de beveget seg mellom de ulike kulturene som deres hverdag bestod av.

\section{Musikk og religiøse erfaringer}

Studentene som nynnet og sang kristne barnesanger i profesjonsfaget hadde muligens en eller annen form for tilknytning til den kristne musikkulturarven. Dette var derfor blitt en del av deres egne musikalske røtter. De hadde kanskje gått i barnekor, hatt en forelder eller besteforeldre som sang for dem da de var små - eller ganske enkelt lært disse sangene på barneskolen. De av studiens deltakere som hadde en religiøs tro eller som hadde foreldre med en religiøs tilknytning, jamfør treets røtter, hadde mange tanker om hvilken betydning musikk hadde for trosutøvelsen deres. Dette handlet blant annet om det tekstlige innholdet i sanger, om lovsang som uttrykk for en opplevd gudsrelasjon og om hvordan troen kunne fungere som inspirasjonskilde. Anniken hevdet at musikk på ulike måter er knyttet til enhver religion:

Det er jo ... jeg tror hver eneste religion har en sang. Og det er jo, det er jo noe som oftest får deg i godt humør og sånn. Også, jeg tenker at det er, selv om jeg ikke er religiøs, så tenker jeg at det er veldig koselig at du har noe - ikke bare måtte lese fra Bibelen, eller lese fra Koranen eller Tanákh, eller hva andre tekster det er jeg ikke husker navnet på - at det faktisk også kan

\footnotetext{
7 Det er en overvekt av sitater hentet fra informanter med en kristen bakgrunn i artikkelen. Dette gjenspeiler datatilfanget i doktorprosjektet (Strøm, 2016). Det er med andre ord ikke en intendert skjevfordeling i utvalget. ${ }^{8}$ De fem ringene over Karlsen's (2011) modell gir ulike innfallsvinkler til å finstille linsen ut fra et fokus på utøving (performance), omforming (transformation), identitet (identity), evne til å skaffe seg tilgang til læringserfaringer (ability to access learning experiences) og styrking av aktørskapet (empowerment) eller en eventuell kombinasjon av ulike filtre.
} 
være litt sånn musikk, og sang, og noe som er enklere å huske. For at det er ofte mye enklere å huske tekst i sang og sånt, selv om, de sangene om Jesus og båten [«Min båt er så liten»], eller noe, det er jo, det har noe mening med det, og de viser barna på en måte liksom at «sånn er det», selv om de ikke klarer å lese Bibelen med alle de vanskelige ordene. Og jeg mener, hvis du har en tro så bør du bare beholde den, så lenge du lissom, men hvis du begynner å lure om det ikke er sant, så er det kanskje på tide å åpne øynene litt, jeg vet ikke. (Anniken, 15 år)

Ulike sanger med religiøst innhold kunne etter Annikens mening hjelpe barn og unge til å huske tekster og dogmer knyttet til den aktuelle religionen. Søndagsskolesanger kan slik sett forstås som eksterne strukturer eller rammefaktorer i barns og unges oppvekst som siden internaliseres og blir viktige komponenter i aktørens interne strukturer. Som Anniken påpeker så vil disse strukturene kunne komme til å utfordres ettersom treet vokser opp, og da må den musikalske aktøren velge om det er noen røtter hun vil rykke opp eller om hun snarere vil dra næring fra dem. Oppfatningen om at enhver religion har sine sanger, støttes av Jack som kom fra en familie med muslimsk bakgrunn:

[Det] at kristne lager sanger om Jesus og lignende, og muslimer gjør, det er jo, det er ikke noe problem det. Det bare viser at dem vil få frem det dem tror på i musikken. Det er egentlig ganske vakkert for å si det sånn. Det har jo betydning. (Jack, 19 år)

På samme måte som søndagsskolesanger kan hjelpe barn til å huske bibelhistorier, så pekte andre informanter på at det finnes muslimske barnesanger, såkalte nasheeds, som formidler islamsk liv og lære (Strøm, 2016, s. 197). Slike og lignende sanger er eksempler på sangtekster som er laget for å lære barn og unge hvordan en troende skal og bør oppføre seg.

Mens sanger kan ha en formidlende og dermed oppdragende funksjon, fortalte andre av ungdommene om hvordan musikk hadde stor betydning for deres gudsforhold. Venninnene Ester og Rebekka fortalte om hvordan lovsang fungerte som et uttrykk for en opplevd gudsrelasjon. Gjennom lovsangen opplevde de at de kunne knytte an til noe større enn seg selv, slik som Rebekka uttrykte det:

Mmm, jeg synes det har veldig stor betydning, egentlig, fordi jeg føler det er liksom noe annerledes enn å bare stå å synge for seg selv, men hvis man synger for noen som på en måte er større enn deg selv, da. (Rebekka, 18 år)

Det å knytte musikk til en opplevelse av å kommunisere med Gud var felles for venninnene Ester og Rebekka, som dette sitatet fra intervjuet med Ester viser:

Eh, jeg, altså, lovsang betyr veldig mye for troen min i hvert fall, fordi - det er en måte å [puster ut] ja, kommunisere med Gud, da. På en slags måte, uttrykke seg selv. Men [ler], jeg føler lovsang har alltid for meg vært, eh, en veldig deilig og beroligende måte å koble til det som er litt større enn deg, større enn oss. Men, så jeg tror det [musikk] er en veldig stor del av tro, egentlig. (Ester, 18 år)

Lovsangen opplevdes både som en avkobling og en tilkobling, der møtet mellom de eksterne strukturene, forstått som lovsangene og lovsangsfellesskapet, og hennes interne strukturer ble utvidet med en transendent dimensjon. Ruud (2013) knytter dette til individets behov for å oppleve seg selv som en «del av noe større, en helhet, en sammenheng» (s. 236). Slike behov har, ved siden av å være deler av aktørens interne strukturer, nær sammenheng med aktørens verdimessige forankring og den musikalske aktørens generelle livsanskuelse. Ifølge Bernard (2009) er evnen til å utøve musikk etter sin aller beste evne, i sammenheng med opplevelsen av å være del av noe større enn en selv, særlige kjennetegn ved en transendent musikalsk erfaring. Nadege delte et musikalsk minne fra sin barndom som nettopp viser musikkens evne til å vekke og styrke en sterk religiøs erfaring, både for henne selv og for andre:

Jeg pleide å synge i kirken min, og på skolen også. Jeg husker jeg pleide å, fordi hver fredag, fordi det er et kristent land, vet du, Kenya, og hver fredag hadde vi disse fellesskapsstingene, 
hvor du bare kan gå opp og synge hvis du har en sang. Og hver fredag, hver eneste fredag hadde jeg alltid en sang, og alle visste det [smiler]. Et virkelig godt minne er, ja, jeg var ung, jeg vet ikke hvor gammel jeg var, kanskje åtte eller noe, og faren min ba meg om å synge, fordi han var presten, og han kalte meg [frem] til å synge ved alteret. Så jeg begynte å synge, og alle var like forundret, vet du. Eh, jeg vet ikke om du noen gang har opplevd det, men det er noen manifestasjoner av Ånden i kirkene, og sånt. Og bare fordi jeg synger, så er det denne damen, og hun ble rørt [av Den hellige Ånd], og hun begynte å gråte, hun kom til føttene mine, og hun rørte ved mine føtter, du vet, så det var så stort for meg. Jeg bare sang, og det var sånn «hva er det som skjer?» [ler svakt]. Men da jeg så videoen, var det akkurat som «wow, jeg gjorde det, jeg fikk henne til å gråte og komme til mine føtter» [vi ler sammen]. Så ja, det var en veldig god opplevelse for meg, ja, det var fantastisk. (Nadege, 18 år)

Det kan virke som at Nadege var vant til åndelige manifestasjoner i kirken, så det spesielle i denne hendelsen, slik jeg forstår det, var det at hun selv bidro til at det skjedde. Denne erfaringen ga henne både anseelse i menigheten og et minne for livet. Det som for et annet barn kunne vært en skremmende opplevelse, var for Nadege en bekreftelse på erfaringer hun hadde internalisert som en naturlig del av det å vokse opp som prestedatter. De var med andre ord blitt en del av hennes generelle disposisjoner og situasjonsspesifikke strukturer. Det kan også tolkes som «a peak experience» (Yob, 2011) som involverer «mind, body and soul» (van der Merwe \& Habron, 2015) på måter som kobler musikk til det hellige for den troende. Etter min oppfatning kan slike musikalske handlinger og erfaringer forstås som frukter på treet.

Ungdom som vokser opp i krysskulturelle kontekster vil nødvendigvis erfare at det eksisterer kryssende oppfatninger av hva som konstituerer passende måter å utøve sine musikalske aktørskap på i relasjon til deres religiøse tro og kulturelle bakgrunn. Alle ungdommene i studien var svært ambisiøse og hadde evne til å gjøre aktiv bruk av de mange musikalske arenaene som var tilgjengelig for dem. Likevel måtte særlig disse ungdommene finne måter å takle kryssende forventninger og fortolkninger på, i seg selv, mellom ulike aktører og mellom aktørene og deres omgivelser.

\section{Forhandlinger og navigeringer i en krysskulturell kontekst}

I denne delen vil jeg fokusere på kryssende verdier i relasjon til musikk og religion og hvordan ungdommene navigerte og forhandlet seg frem til måter å utøve sine musikalske aktørskap på. Det å ha en religiøs tro kan oppleves både givende og utfordrende for ungdom i krysskulturelle kontekster. Ester og Rebekka opplevde blant annet at de fikk inspirasjon fra troen til å følge drømmene sine, skrive sanger og å gjøre verdslige rap og popsanger «kristne». Gjennom disse handlingene opplevde jentene at deres musikalske aktørskap fikk en transendent dimensjon (Ruud, 2013). Dette fortalte de om på helt hverdagslige måter:

Troen min inspirerer meg til å gjøre det jeg vil, og gå etter det jeg tror på, fordi, altså jeg er jo kristen, så jeg tror jo at Gud har lagt, hva skal jeg si, passion i meg, eller, det er han som har lagt det i meg, det at jeg er så glad i musikk. Det troen min har gjort med musikk er å inspirere meg til å faktisk gå etter drømmene mine. (Ester, 18 år)

Det foregikk imidlertid en stadig avveining mellom hva som var, og hva som ikke var, gangbar musikk for en troende uavhengig av hvilken religion de tilhørte. Jack, som muslim, hadde et ganske liberalt syn på hva slags musikk en troende kunne lytte til:

Eh, jeg tror ikke musikk og, asså, religion burde blandes ... men det er to forskjellige ting lissom. Du kan være kristen, du kan være muslim, jøde - du kan høre på $h v a$ slags musikk du vil, egentlig. Musikk er musikk, uansett hva, uansett hvem du er, hvor du er fra - det er ikke noe som burde blandes. Jeg mener på en måte hvis du sier at, eh, vel, eh, rock and roll, da, for 
eksempel er dårlig for muslimer, ikke sant? Det er litt bullshit. Eller at, eh, popsanger ikke er bra for kristne, ikke sant? Det gir ikke mening. (Jack, 19 år)

For Ester og Rebekka opplevdes ikke dette fullt så enkelt. De løste som nevnt problematikken ved å «kristne» popsanger, slik at de kunne brukes i lovsangsbandet i kirken:

Bandlederen, han sier alltid «ja, kan du ikke slenge inn en rap her?» Også bare «okey». Og så bare skriver jeg ned en tekst som jeg tror passer, også bare prøver vi. Vi prøver ut ting, jeg og Rebekka, hvis vi har hørt noe, det er veldig ofte popsanger som vi bare bytter om teksten. Jeg kan gi et eksempel, eh, Kanye West sin sang, han synger sånn «I gotta testify, come up in the spot looking extra fly. For the day I die, I'mma touch the sky», så bare bytter vi teksten og gjør den kristen, og da bare sa vi, hva var det vi sa igjen? «I'm a testify, Jesus gave his life, he was crucified, for the day he died, Jesus touched the sky», for eksempel, da. Ja! [ler] (Ester, 18 år)

På slike måter modifiserte jentene kjente sanger, forstått som eksterne strukturer, slik at de passet til deres egne interne strukturer og trosfellesskapets normer og verdier. Verdi-grunnlaget for disse jentene baserte seg dermed både på ungdomskulturen blant nære venner og påvirkning fra den globale populærkulturen, samtidig som de forholdt seg til sine religiøse verdier. På denne måten bidro Ester og Rebekka til at lovsangsbandet fikk utvidet repertoaret sitt samtidig som de kom den unge delen av menigheten i møte med kjente popmelodier. Mens Ester riktignok hadde nokså lik oppfatning som Jack når det gjaldt hva en troende kunne lytte til; «det å være kristen, det er ikke musikksmak ... du kan like $h v a$ som helst, $h v a$ slags musikk du vil», så viser det følgende sitatet at Nadege opplevde det problematisk for henne, som troende, å lytte til verdslig musikk:

Eh, jeg er en troende og sånt, og du vet, noen ganger må vi virkelig spørre oss selv om «kan vi lytte til denne musikken, kan vi, du vet, danse til denne musikken?» Fordi vi tror at musikk er, kan være en måte å dra deg til noe, det kan tiltrekke deg. For eksempel, du kan bare høre på denne musikken og ville danse til den, og kanskje du egentlig ikke burde danse på den måten, eller du egentlig ikke burde si disse ordene i teksten. ... Musikk er også viktig for de fleste troende, faktisk. Hvordan disse, jeg tror det er som en debatt på gang, og den er slik «bør vi lytte til [denne musikken]/bør vi ikke?» Jeg lytter til langsomme [sanger] og jeg er sånn «det er ingenting galt». Bare trenger ikke å ha disse sterke ordene, du vet, ord som du ikke sier, eller bruker selv. Så hvorfor skal du synge dem? (Nadege, 18 år)

Når musikkens budskap trakk i motsatt retning av hennes eget og trosfellesskapets verdigrunnlag, oppsto det en konflikt. Hun uttrykte at «det er som en debatt på gang», og denne diskusjonen kan ifølge sterk strukturasjon foregå som en indre samtale. Slike samtaler oppstår som følge av verdikonflikter i aktøren selv (Stones, 2005) eller i dette tilfellet også mellom trosfellesskapets og storsamfunnets verdier. Slik jeg tolker Nadege sine uttalelser, så hadde hun internalisert trosfellesskapets verdier, men på tross av dette foregikk det likevel en stadig indre dialog når det gjaldt hvilke sanger hun kunne lytte til som en troende ungdom. Mens Nadege forhandlet seg frem til en posisjon der hun kunne lytte til langsomme sanger, uttalte Naomi at musikk og islam egentlig ikke hører sammen i det hele tatt:

Sss [på innpust], egentlig i religionen min er, eller noen, i hvert fall noen, mener at det er mot religionen, musikk, i religionen min. Det er noen som mener det, og jeg har hørt flere folk som sier at det egentlig ikke er lov å synge, og alt det der. Men tingen er at jeg klarer ikke å ikke synge eller høre på musikk, det er sterkere enn meg. Jeg har prøvd, men det går ikke an, så. Moren min, hun setter gleden min foran alt, så bare «hvis det gjør deg glad, så bare fortsett med det». Jeg har prøvd å slutte å synge, men det går ikke an, nei, det, det, nei, det eksisterer ikke. Jeg og musikk, det er én. Ferdig, ta hele pakka, eller «leave it». (Naomi, 18 år) 
Naomi hadde virkelig forsøkt å etterleve den muslimske normen om at det ikke er lov å synge ${ }^{9}$, men erfart at det var umulig for henne. Det å handle mot normen var kanskje mulig for Naomi fordi hun bor i Norge og at hun dermed ikke hadde hele det somaliske samfunnet rundt seg som fordømte hennes handlinger. Moren, som i denne sammenhengen representerte de religiøse røttene hennes, og samtidig de umiddelbart nære eksterne strukturene, fristilte Naomi fra normer og verdier som ellers ville kunne hindret Naomi fra å være en aktiv musikalsk aktør. En av favorittsangene til Naomi var sangen Wings med jentegruppa Little Mix. Denne opptrådte hun med flere ganger på konserter i regi av det private kultursenteret, og hun fortalte litt om hva den betydde for henne:

Eh, sangen handler om at du ikke skal la andre kutte vingene dine på en måte, og at du skal, du er født med vinger for å bruke dem, du kan fly liksom, ikke la andre slå deg ned liksom. Stol på deg selv, stå på deg selv liksom. Det er, det er en sang som betyr mye. ... For det hadde også en betydning for meg. (Naomi, 18 år)

Sangteksten, som innleder med frasen «Mama told me not to waste my life, she said spread your wings my little butterfly», illustrerer hvordan Naomi hadde evne til å forhandle fram sitt eget handlerom, godt hjulpet av moren. I dette samspillet mellom tekst, melodi og Naomis kontekstuelle bruk av musikken oppstod nye, personlige verdiorienteringer (Stones, 2005) som skilte seg betydelig fra de eksisterende tilgjengelige eksterne strukturene.

Disse ungdommenes fortellinger om deres handlinger knyttet til forholdet mellom musikk og religiøs tro kan som nevnt forstås som måter de bruker musikk aktivt på for å oppfylle sine eksistensielle behov (DeNora, 2000). I den grad slike handlinger skjer innenfor det religiøse fellesskapet, og i den grad aktøren er enig med dette felleskapets normer, vil de kunne bekrefte aktørens indre strukturer. Dersom de snarere kommer i berøring med kryssende sett av normer og verdier, vil utfallet bli ulikt avhengig av individets valg om å bekrefte eller bryte med de eksisterende strukturene. Mens Nadege valgte å innta en forhandlende tilslutning til de gjeldende strukturene, valgte Naomi å bryte med sine. Strukturasjonsteorien (Stones, 2005) åpner for at det er like mye verdighet i begge disse valgene. Slik jeg forstår det, er det bare den enkelte aktør som kan avgjøre hvilket valg som er mest relevant i en krysskulturell kontekst. Hvilke religiøse og kulturelle strukturer den musikalske aktøren velger å gi forrang vil være med på å avgjøre hvilke musikalske handlinger hun kan forsvare overfor seg selv i relasjon til sine verdibaserte overbevisninger.

\section{Avsluttende betraktninger}

I denne artikkelen har jeg analysert ungdommers fortellinger om sitt eget forhold til musikk og religion i en krysskulturell kontekst med utgangspunkt i den sosiologiske teorien om sterk strukturasjon (Stones, 2005). Videre har jeg benyttet meg av det analytiske rammeverket som omhandler musikalsk aktørskap (Karlsen, 2011) for å kunne si noe om ungdommenes bevisste handlinger med og gjennom musikk i relasjon til deres musikalske røtter. I den forbindelse har jeg benyttet meg av treet som metafor (Salole, 2018; Matsunobu, 2007). Røttene kan forstås som aktørens religiøse og kulturelle bakgrunn og disse danner videre grunnlaget for utviklingen av greiner og frukter, forstått som religiøse musikalske praksiser.

Opplevelser av ubehag i musikklærerutdanningen som følge av at medstudenter synger søndagsskolesanger kan som nevnt forstås som en inkluderende holdning til religiøs diversitet i et

\footnotetext{
${ }^{9}$ Dalane (2014) behandler denne problematikken i avsnittet «Jeg synes det er veldig vanskelig å slutte med det [musikk], men jeg prøver. Om dilemmaer, samvittighet og grensesetting» (s. 53) i avhandlingen Mer eller mindre haram? Unge, norske muslimers forhold til musikk og musikkundervisningen i skolen.
} 
mangfoldig samfunn, der er ikke én religion fremheves fremfor andre. På den andre siden kan det forstås som en uavklart holdning til betydningen av skillet mellom religiøst repertoar brakt inn i undervisningen av musikklæreren og det religiøse repertoaret som den enkelte elev bringer med seg til musikkfaget $i$ en krysskulturell kontekst. Presentasjonen av ungdommenes fortellinger om sine egne musikalske aktørskap har gitt et lite innblikk i betydningen av slike forhandlinger for de aktuelle aktørene. Kunnskapsløftet (Utdanningsdirektoratet, 2006) peker på at det er en forutsetning for å oppfylle formålet med musikkfaget i grunnskolen at det arbeides med sjangerbredde og musikalsk mangfold:

Slik kan holdninger til å møte ulike musikalske uttrykk med åpenhet og nysgjerrighet utvikles. I et flerkulturelt samfunn kan faget medvirke til positiv identitetsdanning gjennom å fremme tilhørighet til ens egen kultur og kulturarv, toleranse og respekt for andres kultur og forståelse for musikkens betydning som kulturbærer og verdiskaper lokalt, nasjonalt og internasjonalt. (Læreplan i musikk)

Åpenhet og nysgjerrighet er i Kunnskapsløftet ansett som viktige personlige egenskaper i et mangfoldig samfunn, noe som innebærer at respekt og toleranse overfor ulike trosretninger og verdenssyn er ønskelige karaktertrekk. Fitzpatrick (2012) viser til hvordan kreativitet og personlig uttrykk er verdsatt i musikkundervisningen, og at det derfor er av stor betydning å adressere «the disconnect that students may perceive between home and school cultures» (s. 56). En anerkjennende relasjon forutsetter ifølge Bae og Waastad (1992) «at du er åpen utover, at du greier å lytte og gå inn i den andres opplevelsesverden et øyeblikk» (s. 27). Det er med andre ord viktig å skape en positiv forbindelse mellom musikkfagets repertoar og elevenes musikalske røtter. Dette betyr ikke nødvendigvis at man skal forsikre seg om at man har med en sang for hver religion som er representert i musikklasserommet. Karlsen og Westerlund (2015) fremhever at det er viktig å gjenkjenne forskjellen mellom antatte identiteter og de som velges fritt. Elevers musikalske identitet og preferanser i dagens samfunn kan ha lite å gjøre med deres nasjonalitet og/eller kulturelle eller religiøse bakgrunn. Identitet forstås i denne sammenheng som noe bevegelig og med endringskapasitet. I stedet for å lære elever all verdens musikk, foreslår forfatterne en tilnærming som har som mål å lære seg «the art of living with difference» (s. 372). En kulturelt relevant musikkpedagogikk må anerkjenne hver enkelt elev som aktører med musikalske røtter som har feste i mange ulike retninger. Dette fører til at deres musikalske handlinger, forstått som fruktene på treet, også kan ha mange ulike farger, lukter og smaker.

Through careful and critical consideration of the rich cultural backgrounds that both we and our students bring to the learning experience, and through thoughtful planning for the incorporation of culturally relevant music and pedagogy in our curricula, music teachers and their programs can more effectively serve the needs of their deserving students. (Fitzpatrick, 2012, s. 59)

Det handler altså i like stor grad om hvordan vi tar imot og anerkjenner det repertoaret som elever, og musikklærerstudenter, bringer med seg til undervisningen, som hvilket fellesrepertoar musikklæreren velger å introdusere. Det er spørsmålene vi reiser og samtalene vi fører, uavhengig av hvilken musikk vi velger å gi rom, som avgjør om vi klarer å skape «teachable moments» (Fitzpatrick, 2012) som videre gir mulighet for refleksjon og større kulturell bevissthet. Slike øyeblikk kan gi tid og rom for å tenke gjennom årsaker til at det kan oppstå følelser av ubehag i møte med andres, og kanskje også vår egne, musikalske røtter. 
«Kirken den er et gammelt hus» ${ }^{10}$ - stående ved siden av pulten i tredje klasse synger jeg et helt vers av den gamle salmen utenat. Spontant utbryter læreren min «S! $\rangle^{11}$. Vi har i lekse å pugge salmevers, men det er bare jeg som svarer på oppgaven ved å synge en av dem helt alene. Intuitivt, spontant eller helt bevisst, anerkjenner læreren både min fremførelse og mine musikalske røtter.

\section{Forfatteromtale}

Irene Trønnes Strøm er førsteamanuensis i musikk ved Høgskolen i Innlandet, Norge. Hun har bakgrunn fra musikkpedagogikk- og undervisning, og hennes forskningsinteresser omfatter musikk i barne- og ungdomskultur, herunder utøving av musikalsk aktørskap i krysskulturelle kontekster. Hun underviser ved høgskolens barnehagelærerutdanning, faglærerutdanning i musikk og masterutdanning i Kultur- og språkfagenes didaktikk.

\section{Litteratur}

Bae, B. \& Waastad, J. E. (1992). Erkjennelse og anerkjennelse: Perspektiv på relasjoner. Oslo: Universitetsforlaget.

Bernard, R. (2009). Music making, transcendence, flow, and music education. International Journal of Education \& the Arts, 10(14), 1-21

Cain, M. (2015). Musics of "the other": Creating musical identities and overcoming cultural boundaries in Australian music education. British Journal of Music Education, 32(1), 71-87. doi: https://doi.org/10.1017/S0265051714000394

Campbell, P. S., Drummond, J. D., Dunbar-Hall, P., Howard, K., Schippers, H., \& Wiggins, T. (2005). Cultural diversity in music education: Directions and challenges for the 21st century. Brisbane: Australian Academic Press.

Dalane, M. H. (2014). Mer eller mindre haram? Unge, norske muslimers forhold til musikk og musikkundervisningen i skolen. (Masteravhandling). Det teologiske Menighetsfakultet, Oslo Hentet fra https://brage.bibsys.no/xmlui/bitstream/handle/11250/220027/AVH505-kand-nr-1052masteravh-Dalane-navn.pdf? sequence $=1$ \&isAllowed $=\mathrm{y}$

DeNora, T. (2000). Music in everyday life. Cambridge: Cambridge University Press. doi: https://doi.org/10.1017/CBO9780511489433

Elliott, D. (2013). Multicultural music education. Hentet fra http://www.davidelliottmusic.com/praxial-music-education/multicultural-music-education

Fitzpatrick, K. R. (2012). Cultural diversity and the formation of identity: Our role as music teachers. Music Educators Journal, 98(4), 53-59. doi: https://doi.org/10.1177/0027432112442903

Giddens, A. (1984). The constitution of society: Outline of the theory of structuration. Cambridge: Polity Press.

Harris, D. (2006). Music education and muslims. Stoke on Trent: Trentham Books Ltd.

Heimonen, M., \& Westvall, M. (2015). Multicultural music education from the perspective of Swedish-speaking teachers and state authorities in Finland. Nordisk Musikkpedagogisk Forskning, 16, 139-161. Hentet fra: https://brage.bibsys.no/xmlui/bitstream/handle/11250/2425447/Heimonen_\%26_Westvall_Multicu ltural music education from the perspective.pdf?sequence $=1$ \&isAllowed $=y$

Karlsen, $\bar{S}$. (2011). Using musical agency as a lens: Researching music education from the angle of experience. Research Studies in Music Education, 33(2), 107-121. doi: https://doi.org/10.1177/1321103X11422005

\footnotetext{
${ }^{10}$ Skrevet av N. F. S. Grundtvig i 1837 og tonesatt av L. M. Lindeman i 1840.

${ }^{11} \mathrm{~S}$ - eller Særdeles - var tidligere høyest oppnåelige karakter i ungdomsskolen.
} 
Karlsen, S. (2012). Multiple repertoires of ways of being and acting in music: Immigrant students' musical agency as an impetus for democracy. Music Education Research, 14(2), 131-148. doi: https://doi.org/10.1080/14613808.2012.685460

Karlsen, S. (2013). Immigrant students and the "homeland music": Meanings, negotiations and implications. Research Studies in Music Education, 35(2), 161-177. doi: https://doi.org/10.1177/1321103X13508057

Karlsen, S. (2014). Exploring democracy: Nordic music teachers' approaches to the development of immigrant students' musical agency. International Journal of Music Education, 32(4), 422-436. doi: https://doi.org/10.1177/0255761413515806

Karlsen, S. (2015). Inkludering - av hva og av hvem?: En problematisering av musikkpedagogisk praksis i det flerkulturelle samfunnet. Nordisk Musikkpedagogisk Forskning (Vol. 15, s. 61-84). Oslo: Norges musikkhøgskole.

Karlsen, S. (2017). Policy, Access, and Multicultural (Music) Education. I P. K. Schmidt \& R. Colwell (Red.), Policy and the political life of music education (s. 211-230). New York: Oxford University Press. Doi: https://doi.org/10.1093/acprof:oso/9780190246143.003.0013

Karlsen, S., \& Westerlund, H. (2010). Immigrant students' development of musical agency: Exploring democracy in music education. British Journal of Music Education, 27(03), 225-239. doi: https://doi.org/10.1017/S0265051710000203

Karlsen, S. \& Westerlund, H. (2015). Music teachers' repertoire choices and the quest for solidarity: Opening arenas for the art of living with difference. I C. Benedict, P. Schmidt, G. Spruce \& P. Woodford (Red.), The Oxford handbook of social justice in music education (s. 372-387). New York: Oxford University Press. Doi: https://doi.org/10.1093/oxfordhb/9780199356157.013.24

Kvaal, C. (2018). Kryssende musikkopplevelser: En undersøkelse av samspill i en interkulturell musikkpraksis. (Doktoravhandling). Høgskolen i Innlandet, Elverum.

Matsunobu, K. (2007). Spiritual arts and the education of "Less is more": Japanese perspectives, Western Possibilities. Journal of the Canadian Association for Curriculum Studies, 5(1), 103-119.

Nerland, M. (2004). Musikkpedagogikken og det musikkulturelle mangfoldet. I G. Johansen, S. Kalsnes \& Ø. Varkøy (Red.), Musikkpedagogiske utfordringer: Artikler om musikkpedagogisk teori og praksis (s. 135-148). Oslo: Cappelen akademisk forlag.

Nethsinghe, R. (2012). Finding balance in a mix of culture: Appreciation of diversity through multicultural music education. International Journal of Music Education, 30(4), 382-396. doi: https://doi.org/10.1177/0255761412459166

Ruud, E. (2013). Musikk og identitet (2. utg.). Oslo: Universitetsforlaget.

Salole, L. (2013). Krysskulturelle barn og unge: Om tilhørighet, anerkjennelse, dilemmaer og ressurser. Oslo: Gyldendal akademisk.

Salole, L. (2018). Identitet og tilhørighet: Om ressurser og dilemmaer $i$ en krysskulturell oppvekst (2. utg.). Oslo: Gyldendal akademisk.

Schibbye Løvlie, A.-L. (1993). The role of "recognition" in the resolution of a specific interpersonal dilemma. Journal of Phenomenological Psychology, 24(2), 175-189. doi: https://doi.org/10.1163/156916293X00134

Schippers, H. (2010). Facing the music: Shaping music education from a global perspective. New York: Oxford University Press.

Stones, R. (2005). Structuration theory. Basingstoke: Palgrave. doi: https://doi.org/10.1007/978-0-23021364-7

Strøm, I. T. (2016). "Jeg er ikke norsk, vet du, jeg er internasjonal". En etnografisk studie av musikalsk aktørskap blant ungdom i krysskulturelle kontekster. (Doktoravhandling). Høgskolen i Hedmark, Elverum.

Statistisk Sentralbyrå. (2012). Hva forteller statistikkene om religion, tro og livssyn i Norge? Hentet fra https://www.ssb.no/kultur-og-fritid/artikler-og-publikasjoner/hva-forteller-statistikkene-omreligion-tro-og-livssyn-i-norge

Statistisk Sentralbyrå. (2016). Levekår blant innvandrere i Norge 2016. Hentet fra https://www.ssb.no/sosiale-forhold-og-kriminalitet/artikler-ogpublikasjoner/ attachment/309211? ts $=160 \mathrm{ea9e} 4890$

Sentralbyrå, Sentralbyrå. (2017a). Befolkningsgruppe i stadig endring. Hentet fra https://www.ssb.no/befolkning/artikler-og-publikasjoner/befolkningsgruppe-i-stadig-endring 
Statistisk Sentralbyrå. (2017b). 4 prosent muslimer i Norge? Hentet fra https://www.ssb.no/befolkning/artikler-og-publikasjoner/4-prosent-muslimer-i-norge

Statistisk Sentralbyrå. (2018). Innvandrere og norskfødte med innvandrerforeldre. Hentet fra https://www.ssb.no/befolkning/statistikker/innvbef

Sæther, E. (2008). When minorities are the majority: Voices from a teacher/researcher project in a multicultural school in Sweden. Research Studies in Music Education, 30(1), 25-42. doi: $10.1177 / 1321103 \times 08089888$

Sæther, E. (2010). Music education and the Other. Finnish Journal of Music Education, 13(1), 45-60.

Utdanningsdirektoratet. (2018). Laereplan i musikk (MUS1-01). Hentet fra https://www.udir.no/k106/MUS1-01/Hele/Formaal

van der Merwe, L. \& Habron, J. (2015). A conceptual model of spirituality in music education. Journal of Research in Music Education, 63(1), 47-69. doi: https://doi.org/10.1177/0022429415575314

Volk, T. M. (1998). Music, education, and multiculturalism: Foundations and principles. New York: Oxford University Press.

Westerlund, H., Partti, H., \& Karlsen, S. (2016). Identity formation and agency in the diverse music classroom. In R. A. R. MacDonald, D. J. Hargreaves, \& D. Miell (Red.), The Oxford handbook of musical identities (s. 493-509). Oxford: Oxford University Press. doi: https://doi.org/10.1093/acprof:oso/9780199679485.003.0027

Yob, I., M. (2011). If we knew what spirituality was, we would teach for it. Music Educators Journal, 98(2), 41-47. doi: https://doi.org/10.1177/0027432111425959 